\title{
Marijuana Exposure During Lactation: Is It Safe?
}

\author{
Alice Ordean \\ Medical Director, Toronto Centre for Substance Use in Pregnancy, St. Joseph's Health Centre, Toronto and \\ Assistant Professor, Department of Family and Community Medicine, University of Toronto, Toronto, Ontario, \\ Canada \\ ordeaa@stjoe.on.ca
}

Received date: 25 September 2013; Accepted date: 22 November 2013; Published date: 24 January 2014

Academic Editor: Loretta P. Finnegan

Copyright (C) 2014. Alice Ordean. Distributed under Creative Commons CC-BY 3.0

\begin{abstract}
The aim of this paper is to provide a systematic review of the evidence regarding the safety of cannabis exposure during lactation and recommendations for clinical practice. PubMed and OVID Medline search was performed using pregnancy, breastfeeding, cannabis, and marijuana. Articles were limited to human studies and English language. Animal studies, case reports, reviews and letters were excluded. Four studies were included in this review. Based on current evidence, there is one study reporting a potential effect of marijuana on motor development at one year of age. However, this finding was not repeated in other studies. Most evidence of harm is associated with prenatal exposure. Women need to be advised that the risk of exposure to marijuana during lactation remains uncertain; therefore, risks and benefits of marijuana use need to be considered before deciding to breastfeed.
\end{abstract}

Keywords: lactation, postnatal exposure, marijuana, infant development

\section{Introduction}

Cannabis is the most commonly used illicit drug in Canada. The true prevalence during pregnancy remains unknown. Based on data from the Canadian Alcohol and Drug Use Monitoring Survey (CADMUS), 6.2\% of women reported past year use of cannabis (Health Canada 2012). Results from the 2010 National Survey on Drug Use and Health (NSDUH) also estimated the rate of illicit drug use by pregnant women in the US at $\sim 5 \%$ (SAMHSA 2011). According to the Canadian Maternity Experiences Survey, up to $7 \%$ of pregnant women reported street drug use in the 3 months prior to becoming pregnant or being aware of their pregnancy (Public Health Agency of Canada 2009). This proportion reduced to $1 \%$ once pregnancy was diagnosed.

The active ingredient of cannabis called $\triangle^{9}$. tetrahydrocannabinol (THC) is fat soluble and 
distributes fast into brain and fatty tissue resulting in 8 fold accumulation in breast milk in comparison to plasma (Liston 1998). THC has been shown to cross the placenta and to be secreted in maternal milk during lactation (Perez-Reyes and Wall 1982). THC was also demonstrated in newborn fecal material indicating systemic absorption of marijuana and metabolism. Therefore, breastfeeding infants are exposed to THC during the development of the central nervous system (Tennes et al 1985, Astley and Little 1990).

Given that $\sim 90 \%$ of Canadian women initiate breastfeeding, it is concerning that neonates may be exposed to cannabis during early infancy. Research evidence from two long-term follow-up studies indicates that antenatal exposure to marijuana may lead to negative outcomes such as behaviour problems and attention deficit hyperactivity disorder, yet the effects of marijuana exposure during lactation has not been widely studied (Fried 1985, Day 1991). A review of cannabis use during breastfeeding was published in 2009 (Garry et al. 2009). This article advised women who use cannabis to discontinue breastfeeding despite the lack of sufficient evidence for this strong recommendation. Women rely on health care providers' advice about the safety of marijuana use during lactation; however, conflicting information is usually provided due to the lack of knowledge. The purpose of this article is to systematically review the evidence regarding the effects of cannabis use while breastfeeding and to provide evidence-based clinical advice for breastfeeding women.

\section{Methods}

A search of PubMed and Ovid MEDLINE from 1946 to March 2013 was conducted using the following keywords: breastfeeding, lactation, marijuana and cannabis. Articles were limited to English language and human studies. Cohort and case-control studies were included if they reported on the effects of marijuana exposure during lactation. Studies reporting non-human research, case reports, reviews and letters were excluded. Reference lists from obtained articles were also reviewed for other articles. Data relating to maternal demographics, marijuana use and developmental assessment outcomes were extracted and summarized in tables 1 and 2 below. Quality of evidence was assessed using the GRADE system and included in table 2 (Guyat et al. 2008).

\section{Results}

Fourteen articles met inclusion criteria. Ten articles were further excluded based on the following reasons: two addressed HIV exposure, three explored other substance use (alcohol, herbs) and five focused on other areas not related to the topic searched (e.g. gene expression, psychoanalytical study, triangulation in cross-cultural research). Therefore, four articles were included in the final review.

Demographics of women participating in these studies were consistent with their geographical location (see table 1). Age, race and socioeconomic status varied among the studies. Two studies consistently reported that women who used marijuana while breastfeeding were also more likely to use alcohol, tobacco and other illicit drugs - these co-exposures have been identified as possible confounding factors for developmental assessment (Tennes et al. 1985, Frank et al.1992). This finding is consistent with other studies which have also documented polysubstance use among cigarette smokers (Gaalema et al. 2013). Among pregnant women enrolled in a smoking cessation trial, marijuana was the most prevalent illicit drug used.

Extent of marijuana exposure and associated outcomes are summarized in table 2. Two of the articles addressed effects of marijuana exposure during lactation on infant mental and motor development at one year of age using validated screening tools such as the Bayley Scales of Infant Development (Astley and Little 1990, Tennes et al. 1985). Both of these outcome studies were prospective trials performed in the USA. Tennes et al. (1985) found no significant difference between users and nonusers in terms of postnatal marijuana exposure and infant growth and development 
at one year. Astley \& Little (1990) also demonstrated no effect of maternal marijuana exposure during the first month of lactation on mental development at one year of age. However, physical development was found to be affected by marijuana use during the first month postpartum. It is unclear if this is a true effect of marijuana exposure while breastfeeding since exposure during first trimester of pregnancy was also found to be responsible for contributing to this outcome, yet marijuana use during the third month of lactation failed to have any detrimental effect.

The association between marijuana and sudden infant death syndrome (SIDS) was addressed by one study. Frank et al (1992) conducted a retrospective case-control study of infants who died from SIDS comparing maternal and paternal smoking history. SIDS was not significantly associated with maternal marijuana use at any point during conception, pregnancy or postnatal period. However, SIDS was found to be associated with paternal marijuana use during the same time periods, even after accounting for cigarette smoking and alcohol history, which may point towards the negative effect of second hand smoke exposure on the risk of SIDS.

Another article investigated the effect of marijuana use on rates of breastfeeding but did not determine long-term outcomes. KlonoffCohen \& Lam-Kruglick (2001) showed that marijuana use decreased during pregnancy from the first to the third trimester especially among those planning to breastfeed. By delivery, $5 \%$ of women intending to breastfeed had a positive urine drug screen for marijuana in comparison to $8 \%$ among those planning to bottle feed.

\section{Discussion}

This limited evidence fails to provide any conclusive data on the possible outcomes related to marijuana exposure during lactation. Pregnant women seem concerned about potential risks and as a result, are motivated to reduce marijuana during pregnancy. However, the rate of relapse to marijuana use postpartum has not been determined. Resumption of marijuana use during the postpartum period may lead to increased exposure during lactation.

Limitations of human studies included the following: role of confounding variables such as prenatal marijuana exposure, passive exposure to marijuana and maternal/infant interactions on development, as well as, marijuana use based on self-report may be more likely to lead to recall bias and under-reporting. Given the paucity of data on the risks of marijuana exposure during lactation, it does not seem possible that prenatal and postnatal exposure can be investigated separately. Therefore, future studies need to determine ways to differentiate effects of marijuana use at various points in time.

Animal studies have been more extensive due to the potential to account for several confounding factors identified by human studies. Results from these preclinical animal trials of the effects of cannabis exposure during pregnancy and/or lactation indicate that cannabis is a neuroteratogen which can lead to long-lasting behavioral abnormalities [Campolongo et al. 2011]. This outcome is not specific to breastmilk exposure and may be more likely related to antenatal use.

Until further evidence becomes available, women should be counselled to abstain from marijuana use during breastfeeding since the use of marijuana while breastfeeding may pose some risk on developmental outcomes. However, women who are not able to abstain should consider reducing their marijuana use and continue with breastfeeding since the benefits of breastfeeding are substantial. The final decision for breastfeeding should be patient driven after a benefit-risk discussion with their health care provider.

\section{Conclusion}

Given the prevalence of marijuana exposure during pregnancy and lactation, it is important to provide evidence-based information about these potential exposures. Based on 
preliminary and conflicting results, the true effect of marijuana exposure during lactation is not known. Pregnant women should be counselled regarding the benefits of breastfeeding and risks of marijuana exposure before making a decision to breastfeed.

Table 1: Description of included studies and maternal demographics

\begin{tabular}{|c|c|c|c|c|}
\hline $\begin{array}{l}\text { Author, } \\
\text { year }\end{array}$ & Location & Type of study & $\begin{array}{l}\text { Number } \\
\text { included }\end{array}$ & Demographics \\
\hline $\begin{array}{l}\text { Tennes K et } \\
\text { al. } \\
1985\end{array}$ & $\begin{array}{l}\text { Denver, } \\
\text { CO, USA }\end{array}$ & $\begin{array}{l}\text { Prospective } \\
\text { cohort study }\end{array}$ & $\begin{array}{l}756 \text { women } \\
\text { participated } \\
\text { postpartum } \\
\text { (recruited from } \\
\text { women } \\
\text { attending } \\
\text { prenatal care } \\
\text { clinics) }\end{array}$ & $\begin{array}{l}\text { Younger age } 21.8 \text { yrs } \\
\text { more single/cohabiting } \\
\text { fewer prior live births } \\
\text { lower-middle to lower SES } \\
\text { alcohol, nicotine and other illicit } \\
\text { drugs more frequently used by } \\
\text { marijuana smokers }\end{array}$ \\
\hline $\begin{array}{l}\text { Astley SJ, } \\
\text { Little RE } \\
1990\end{array}$ & $\begin{array}{l}\text { Seattle, } \\
\text { WA, USA }\end{array}$ & $\begin{array}{l}\text { Prospective } \\
\text { case-control } \\
\text { study }\end{array}$ & $\begin{array}{l}136 \text { total } \\
68 \text { lactation } \\
\text { exposed vs. } \\
68 \text { non-exposed }\end{array}$ & $\begin{array}{l}\text { Age } 28.3 \text { years (range } 18-41 \text { ) } \\
\text { married } 86 \% \\
\text { primarily white, middle class } \\
\text { college educated }\end{array}$ \\
\hline $\begin{array}{l}\text { Frank DA et } \\
\text { al. } \\
1992\end{array}$ & $\begin{array}{l}\text { Boston, } \\
\text { MA, USA }\end{array}$ & $\begin{array}{l}\text { Prospective } \\
\text { cohort study }\end{array}$ & $\begin{array}{l}1210 \text { pregnant } \\
\text { women: } 628 \\
\text { intending to } \mathrm{BF} \text {, } \\
582 \text { intending to } \\
\text { bottlefeed }\end{array}$ & $\begin{array}{l}\text { No significant differences between } \\
\text { two groups } \\
\text { Users - more likely black, unmarried, } \\
\text { born in US, primiparous, } \\
\text { more likely to be heavy users of } \\
\begin{array}{l}\text { cigarettes \& alcohol during } \\
\text { pregnancy }\end{array}\end{array}$ \\
\hline $\begin{array}{l}\text { Klonoff- } \\
\text { Cohen H, } \\
\text { Lam- } \\
\text { Kruglick P } \\
2001\end{array}$ & $\begin{array}{l}\text { San Diego, } \\
\text { CA, USA }\end{array}$ & $\begin{array}{l}\text { Retrospective } \\
\text { case-control } \\
\text { study }\end{array}$ & 478 infants & Not available \\
\hline
\end{tabular}


Table 2: Developmental outcomes

\begin{tabular}{|c|c|c|}
\hline $\begin{array}{l}\text { Author, year and } \\
\text { GRADE quality of } \\
\text { evidence }\end{array}$ & Marijuana exposure & Results of developmental assessments \\
\hline $\begin{array}{l}\text { Tennes K et al. } \\
1985 \\
\text { Low quality }\end{array}$ & $\begin{array}{l}34 \% \text { used marijuana during } \\
\text { pregnancy } \\
\sim 50 \% \text { of women BF at } 1 \text { year } \\
\text { reported using marijuana; } 12 \\
\text { smoked once a month or less, } 9 \\
\text { weekly and } 6 \text { daily }\end{array}$ & $\begin{array}{l}\text { Mental \& motor development at } 1 \text { year of age: } \\
\text { No significant differences in duration of BF among } \\
\text { two groups } \\
\text { No effects of postnatal marijuana exposure on infant } \\
\text { growth or on mental/motor development }\end{array}$ \\
\hline $\begin{array}{l}\text { Astley SJ and } \\
\text { Little RE } \\
1990 \\
\text { Moderate quality }\end{array}$ & $\begin{array}{l}20-24 \% \text { reported marijuana use } \\
\text { at least once a week during } \\
\text { pregnancy or lactation (usually } 1 \\
\text { joint; 5-10\% smoked } 2-5 \\
\text { joints/day) } \\
84 \% \text { of women who used during } \\
\text { pregnancy continued to use } \\
\text { during lactation } \\
\text { Proportion of women smoking } \\
\text { daily increased from pregnancy } \\
\text { to postpartum: } 5 \% \text { during } \\
\text { pregnancy, } 7 \% \text { at lactation month } \\
\text { one and } 10 \% \text { at lactation month } \\
\text { three }\end{array}$ & $\begin{array}{l}\text { Mental \& motor development at } 1 \text { year of age: } \\
\text { Association between daily marijuana exposure } \\
\text { during first month of lactation \& lower PDI score by } \\
14 \text { points; confounded by marijuana exposure } \\
\text { during first trimester } \\
\text { No effect on PDI score with marijuana use during } \\
\text { third month of lactation } \\
\text { No significant effect on mental development at one } \\
\text { year of age }\end{array}$ \\
\hline $\begin{array}{l}\text { Frank DA et al. } \\
1992 \\
\text { Low quality }\end{array}$ & $\begin{array}{l}10 \% \text { of intention to } \mathrm{BF} \text { women } \\
\text { used marijuana in } \mathrm{T} 1 \text {, decreased } \\
\text { to } 5 \% \text { by delivery } \\
15 \% \text { of intention to bottlefeed } \\
\text { group used marijuana in } \mathrm{T} 1 \text {, } \\
\text { decreased to } 8 \% \text { by delivery } \\
50 \% \text { used weekly }\end{array}$ & $\begin{array}{l}\text { Maternal characteristics \& health habits correlated } \\
\text { with cocaine and marijuana use } \\
\text { Women intending to BF were less frequent users of } \\
\text { marijuana than those intending to bottle feed ( } 21 \% \\
\text { vs. } 33 \%)\end{array}$ \\
\hline $\begin{array}{l}\text { Klonoff-Cohen H, } \\
\text { Lam- Kruglick P } \\
2001 \\
\text { Very low quality }\end{array}$ & $\begin{array}{l}14 \text { women in each group smoked } \\
\text { marijuana during pregnancy and } \\
10 \text { mothers in case group vs. } 11 \\
\text { mothers in control group smoked } \\
\text { postpartum - no significant } \\
\text { difference }\end{array}$ & $\begin{array}{l}\text { SIDS (sudden infant death syndrome) - based on } \\
\text { autopsy report } \\
\text { SIDS not significantly associated with maternal } \\
\text { marijuana use at any point in time } \\
\text { SIDS was associated with paternal marijuana use } \\
\text { during any period (after controlling for smoking } \\
\text { and alcohol) }\end{array}$ \\
\hline
\end{tabular}




\section{References}

1.Astley, S. J. and Little, R. E. (1990) "Maternal marijuana use during lactation and infant development at one year," Neurotoxicology and teratology, 12(2), 161-168.

2. Campolongo, P., Trezza, V, Ratano, P, Palmery, M. and Cuomo, V. (2011) "Developmental consequences of perinatal cannabis exposure: behavioral and neuroendocrine effects in adult rodents," Psychopharmacology, 214, 515.

3. Day, N.L., Sambamoorthi, U., Taylor, P., Richardson, G., Robles, N., John, Y., Scher, M., Stoffer, D., Cornelius, M. and Jasperse, D. (1991) "Prenatal marijuana use and neonatal outcomes," Neurotoxicology and Teratology, $13,329-334$

4. Frank, D. A, Bauchner, H, Zuckerman, B. S. and Fried L. (1992) "Cocaine and marijuana use during pregnancy by women intending and not intending to breastfeed," Journal of the American Dietetic Association, 92(2), 215217.

5. Fried, P.A. (1985) "Postnatal consequences of maternal marijuana use" in T.M. Pinkert (Ed.), Current Research on the Consequences of Drug Abuse, 61-72. Rockville, MD: National Institute on Drug Abuse.

6. Gaalema, D. E, Higgins, S. T, Pepin, C. S, Heil, S. H. and Bernstein, M. (2013) "Illicit drug use among pregnant women enrolled in treatment for cigarette smoking cessation," Nicotine Tob Res, 15(5), 987-991.

7. Garry, A, Rigourd, V., Amirouche, A., Fauroux, V., Aubry, S. and Serreau, R. (2009) "Cannabis and breastfeeding," Journal of Toxicology, 1-5.

8. Guyatt, G.H., Oxman, A.D., Vist, G., Kunz, R., Falck-Ytter, Y., Alonso-Coello, P.,
Schünemann, H.J., for the GRADE Working Group. (2008) "Rating quality of evidence and strength of recommendations GRADE: an emerging consensus on rating quality of evidence and strength of recommendations", BMJ, 336, 924-926.

9. Health Canada 2012. Canadian alcohol and drug use monitoring survey (CADUMS), Controlled Substances and and Tobacco Directorate.

10.Klonoff-Cohen, H. and Lam-Kruglich, P. (2001) "Maternal and paternal recreational drug use and sudden infant death syndrome," Arch Pediatr Adolesc Med, 155, 767-770.

11.Liston J. (1998) "Breastfeeding and the use of recreational drugs - alcohol, caffeine, nicotine and marijuana", Breastfeeding Review, 6(2), 27-30.

12.Perez-Reyes M., and Wall, M.E. (1982). "Presence of $\triangle^{9}$-tetrahydrocannabinol in human milk", NEJM, 307(13), 819-20.

13.Public Health Agency of Canada (2009). What Mothers Say: The Canadian Maternity Experiences Survey. Ottawa.

14. Substance Abuse and Mental Health Services Administration (SAMHSA) 2011. Results from the 2010 National Survey on Drug Use and Health: Summary of National Findings, NSDUH Series H-41, HHS Publication No. (SMA) 11-4658. Rockville, MD: Substance Abuse and Mental Health Services Administration.

15.Tennes, K., Avitable, N., Blackard, C., Boyles, C., Hassoun, B., Holmes, L. and Kreye M. (1985) "Marijuana: prenatal and postnatal exposure in the human," NIDA research monograph, 59, 48-60. 